IZA DP No. 4429

The Political Economy of Conscription

Panu Poutvaara

Andreas Wagener

September 2009

Forschungsinstitut zur Zukunft der Arbeit Institute for the Study of Labor 


\title{
The Political Economy of Conscription
}

\author{
Panu Poutvaara \\ University of Helsinki \\ and IZA
}

Andreas Wagener
University of Hannover

\section{Discussion Paper No. 4429 \\ September 2009}

\author{
IZA \\ P.O. Box 7240 \\ 53072 Bonn \\ Germany
}

Phone: +49-228-3894-0

Fax: +49-228-3894-180

E-mail: iza@iza.org

Any opinions expressed here are those of the author(s) and not those of IZA. Research published in this series may include views on policy, but the institute itself takes no institutional policy positions.

The Institute for the Study of Labor (IZA) in Bonn is a local and virtual international research center and a place of communication between science, politics and business. IZA is an independent nonprofit organization supported by Deutsche Post Foundation. The center is associated with the University of Bonn and offers a stimulating research environment through its international network, workshops and conferences, data service, project support, research visits and doctoral program. IZA engages in (i) original and internationally competitive research in all fields of labor economics, (ii) development of policy concepts, and (iii) dissemination of research results and concepts to the interested public.

IZA Discussion Papers often represent preliminary work and are circulated to encourage discussion. Citation of such a paper should account for its provisional character. A revised version may be available directly from the author. 
IZA Discussion Paper No. 4429

September 2009

\section{ABSTRACT}

\section{The Political Economy of Conscription}

Though in decline recently, military conscription is still a widely used mode of staffing armies. Since not many valid economic, social or military arguments in favor of the draft can be put forward, the question emerges why societies choose to rely on it. In this survey we explain the political allure of military conscription by its specific intra- and intergenerational incidence as a tax. From a public choice perspective, there is always a vast majority of people in favor of the introduction and maintenance of military draft, as compared to a professional army. Empirical evidence for this conclusion appears to be mixed, however. Political preferences with respect to conscription involve concerns about its unfairness and questionable record on social accounts. Special interests may also matter.

JEL Classification: H56, D72

Keywords: military draft, public choice, taxation, dynamic costs, fairness

Corresponding author:

Panu Poutvaara

Department of Economics

Arkadiankatu 7 (P.O. Box 17)

00014 University of Helsinki

Finland

E-mail: panu.poutvaara@helsinki.fi

\footnotetext{
* This paper is forthcoming as a chapter in The Handbook on the Political Economy of War, edited by Christopher Coyne (West Virginia University) and to be published by Edward Elgar Publishing Ltd. We are grateful for helpful comments by Chris Coyne. Panu Poutvaara gratefully acknowledges financial support from the Yrjö Jahnsson Foundation.
} 


\section{Introduction}

Forced labor is no longer exacted by today's non-totalitarian states - except in the forms of compulsory military service and its unarmed corollaries such as civil, alternative or social service. Conscription (military draft) is the legal obligation for persons from a certain demographic subgroup to perform military service; in practice this obligation is usually imposed on young men. ${ }^{1}$ Non-compliance with the draft is typically considered a felony, punishable by imprisonment or, in case of war, even death. After their active duty, conscripts often remain in military reserve for some additional period.

Historically, conscription is quite novel (see Keegan, 1993, for a thorough account). While rulers at all times pressed their subjects into military service whenever they wished so, ${ }^{2}$ such draft schemes (militias) were occasional, selective and non-systematic. In $14^{\text {th }}$ century Italy, hired professionals started to replace citizen militias; mercenaries and commercialized warfare dominated the European battlefields until the late $18^{\text {th }}$ century. The birth of general military conscription is usually dated back to 1793 when the French National Convention called a levée en masse. However, in 1800 the generality of the French conscription scheme was abandoned when citizens were allowed to buy themselves out of military service. Basically, it was Prussia under its king Friedrich Wilhelm III that in 1814 first installed a universal scheme of conscription without exceptions (apart for those found unable to deliver military service). The military successes of the Prussian and Napoleonic conscripted armies inspired many countries to adopt universal conscription, and the industrialized, high-intensity mass wars of the late $19^{\text {th }}$ and $20^{\text {th }}$ centuries were only feasible because compulsory military service made available millions of young men as soldiers. During and after World War II, military conscription was the dominant recruitment method for armies around the world, in democratic as well as in authoritarian regimes. With the end of the Cold War, draft systems are in retreat in democratic countries (Haltiner, 2003). Several countries abolished the military draft in favor of a professional army while others are debating

\footnotetext{
1 Unlike the rest of the world, Eritrea, Israel, Libya, Malaysia, North Korea, Taiwan, and Tunisia currently also draw women into compulsory military service or its equivalents. Formally, compulsory military service for women also exists in China (but has never been enforced).

2 Examples include feudal levies, military slaves, serfs with lifetime conscription, allotment systems, or armed peasants.
} 
such a step. Seven out of the 26 NATO members ${ }^{3}$ still run their armies with conscripts, and the draft heavily intrudes into the lives of young men in many Asian countries (including China), in most successor states of the Soviet Union, as well as throughout Latin America, Africa, and the Middle East (see Figure 1).

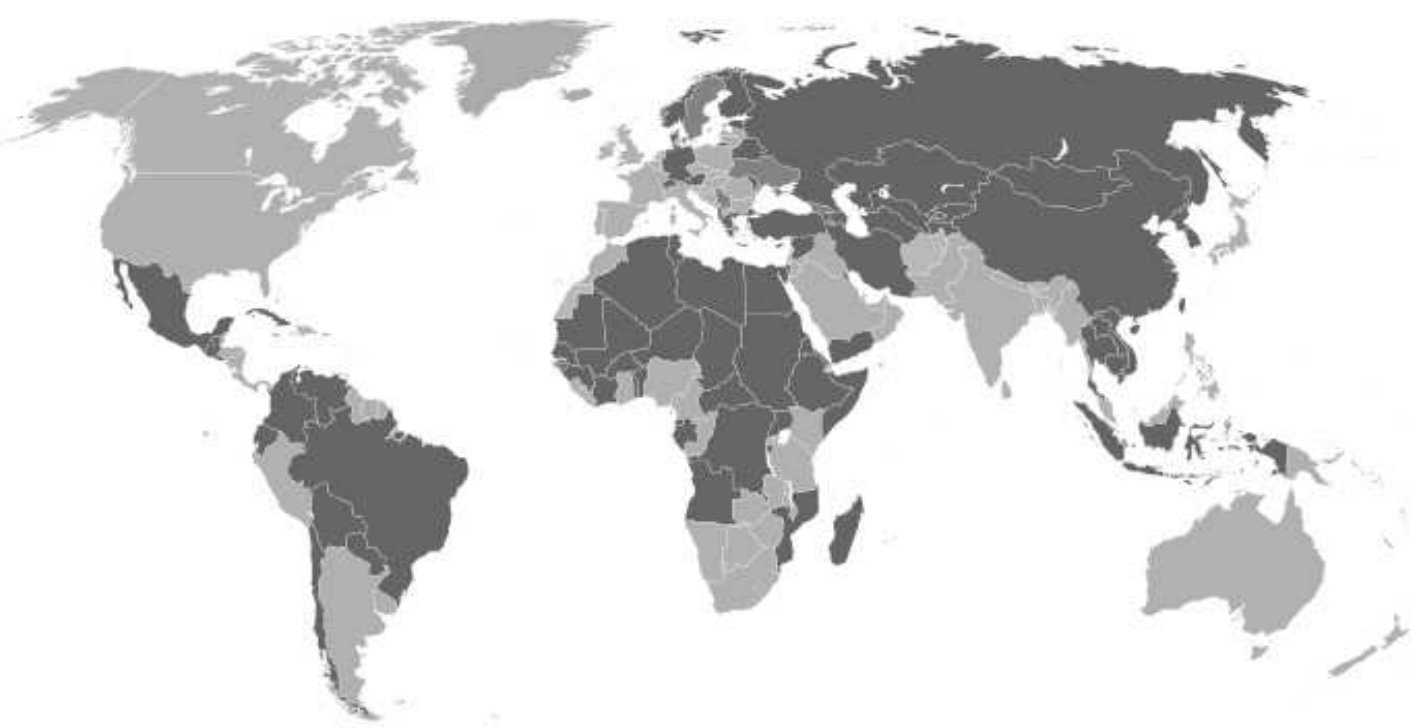

Light: $\quad$ No conscription

Dark : Conscription

Medium: Plan to abolish conscription within three years

Exceptions: Costa Rica, Greenland, Haiti, Iceland, Panama (no own armed forces), Iraq, Western Sahara (no official information)

Figure 1: Conscription throughout the world, 2009.

Source: Wikipedia (2009)

While the duration of military service is currently one year or less in most European countries, it is typically between 18 and 24 months elsewhere; some countries have even longer periods of service. ${ }^{4}$

\footnotetext{
3 These are Austria, Denmark, Estonia, Germany, Greece, Norway, and Turkey.

$4 \quad$ Most notably: North Korea (three to ten years of compulsory military service), South Korea (24-28 months), or Syria (30 months). See https://www.cia.gov/library/publications/the-worldfactbook/fields/2024.html.
} 
Historically, the rise of military conscription coincided with the emergence of the nation state and the idea of citizen rights. Military service was considered as one of the duties by which citizens paid for their increased rights of political participation (Levi, 1998). Likewise, the emergence of professional soldiers and the commercialization of warfare in Renaissance Italy were associated with the expansion of the economic powers of merchants and bankers; by hiring foreign mercenaries locals bought themselves out of direct involvement in warfare and could fully specialize in trade and banking (McNeill, 1982). These observations indicate a strong linkage between various military recruitment formats and the political economy, which we survey in this chapter. Our main goal is to shed light on the question of why countries continue to embrace military conscription.

Our analysis proceeds as follows. We argue that the military draft is a tax. While appearing inefficient relative to an all-volunteer army, which also requires the government's power to tax, the draft comes with a specific incidence within and across age cohorts: it primarily burdens young males (Section 2). From the perspective of political economy (in its version of public choice), this implies that the introduction and the maintenance of military draft would always find support by a majority of the population (Section 3.1). However, the empirical evidence for this conclusion appears to be mixed (Section 3.2). While parts of the decline of conscription may be attributed to a change in military threats, it also seems that political preferences against conscription involve concerns about its unfairness and questionable record on social accounts (Section 4). Still, societal groups (e.g., trade unions, the military, bureaucracy, or the welfare industry) that benefit from military conscription may form special interest groups that actively lobby against its abolition (Section 5). Sections 6 and 7 discuss the military record of conscription and the political economy of mercenaries. Section 8 concludes.

It should be noted that most democratic countries with conscription grant the right to conscientious objectors against military service to comply with their duty to serve in forms of an alternative service, sometimes called civil or social service. If available, unarmed alternative service is typically longer than military service. All economic arguments against, and most aspects of political economy associated with military conscription apply, mutatis mutandis, also to alternative service. 


\section{The draft as a tax: Efficiency and incidence}

Currently, the most common alternative to military conscription for recruiting personnel into armies (as well as into reserves) are volunteers, hired for a certain period on the labor market and financed out of general tax revenues. ${ }^{5}$ Pure conscript armies do not exist; some career officers are always needed to train conscripts and to command the troops. Yet we speak of a conscript army when at least part of the army and reserves consist of citizens who are ordered to serve. Moreover, we use the terms "volunteer force” and "professional army” interchangeably and apply them both to standing armies and to reserves. Figure 2 visualizes various military recruitment formats.

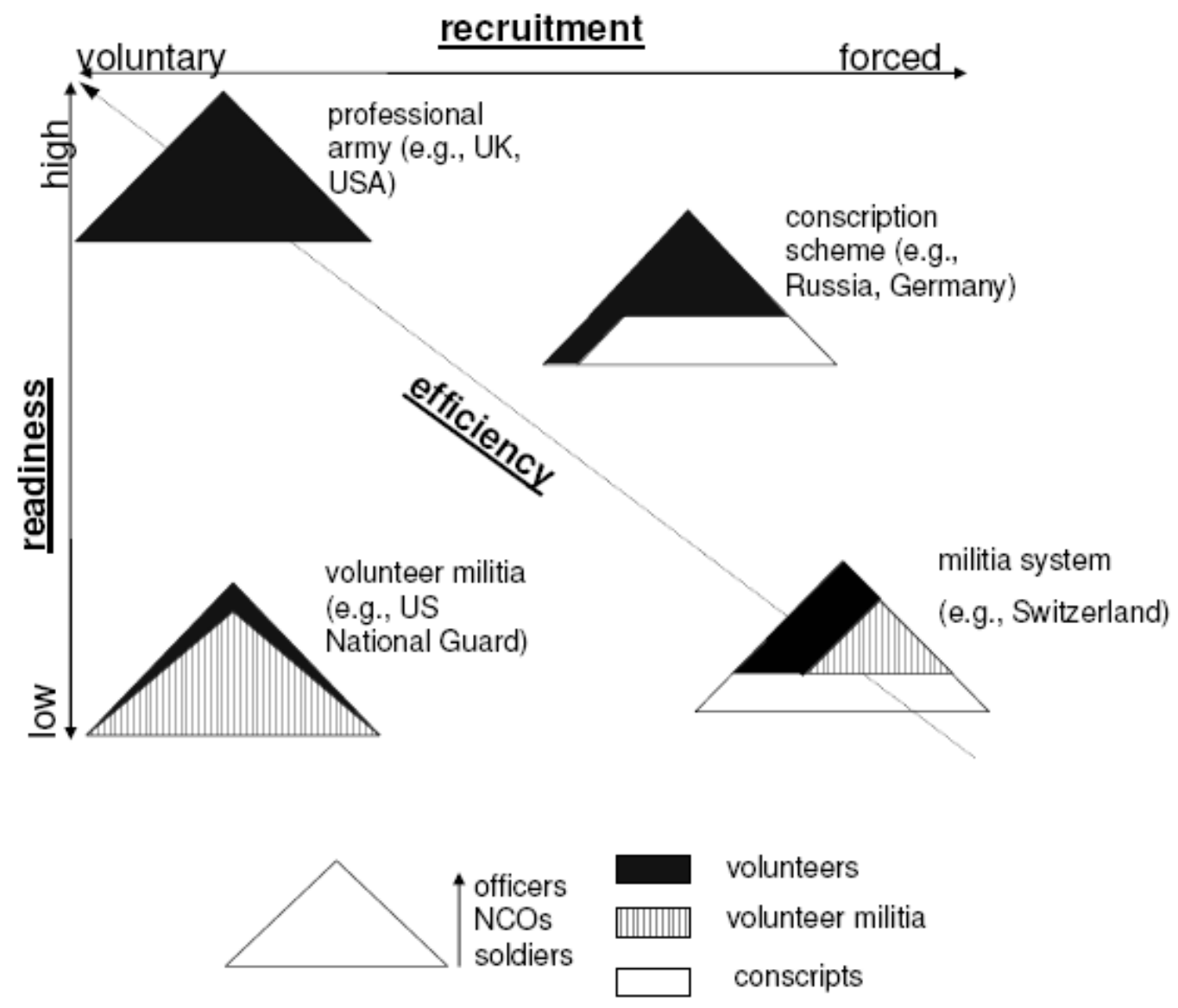

Figure 2: $\quad$ Military recruitment formats.

Adapted from Haltiner (1998). armed conflict. Perhaps the best-know example is the system of National Guards in the United States that, in addition to serving as military reserves, help to respond to domestic disasters. 
The relative merits of military draft and professional armies have been debated for centuries by military strategists, historians, political scientists, and economists (for recent surveys see Sandler and Hartley, 1995, Chapter 6; Warner and Asch, 2001, or Poutvaara and Wagener, 2007a). Economically, a military draft is a tax in the form of coerced and typically underpaid labor services. Its alternative, the professional army, compensates soldiers with the revenues from fiscal (i.e., money) taxes. Conscript forces and professional armies, thus, represent two different tax modes to "finance" military personnel: in-kind or fiscal.

\subsection{Specialization and production efficiency}

Economists generally hold that a military draft is the inferior way to raise an army. Adam Smith made a clear case against conscription and found an "irresistible superiority which a well-regulated standing [i.e., all-volunteer] army has over a militia [i.e., temporary conscription]" (Smith 1976, p. 701). Smith's arguments focus on comparative advantage and the benefits from specialization.

The principle of comparative advantage demands that jobs be assigned to individuals who are relatively more productive than others in doing them. By forcing everybody into a military occupation, irrespective of their relative productivities, military conscription violates that principle and involves an inefficient match between people and jobs. Benefits from specialization arise when individuals, after being employed for a single set of tasks over a longer period, become more productive than those with less experience. Effective warfare or defense operations require a considerable degree of training and mastery in handling complex weapon systems. By lack of specialization, drafted short-term soldiers are inferior to long(er)-term professionals. Societies that rely on military conscription thus forego productivity gains. In total, armies tend to be economically more efficient the more they are based on volunteerism and the more permanent they are. In Figure 2, this is indicated by the diagonal arrow. 


\subsection{Opportunity costs and excess burden}

In terms of the government budget, operating a draft system is generally cheaper than a professional army: Conscripts are only paid some pocket money rather than the market value of their labor service, and fringe benefits such as health plans, family support, old-age provisions etc. are granted to draftees on a much smaller scale than for professional soldiers (if at all). ${ }^{6}$ However, accounting costs do not reflect the real opportunity costs of a conscript army; the use of compulsion in itself suggests that real costs are higher. The social cost of drafting someone to be a soldier is not what the government chooses to pay him but the minimum amount for which he would be willing to join the army voluntarily. The discrepancy between budgetary and opportunity costs is substantial. For example, Kerstens and Meyermans (1993) estimate that the social cost of the (now abolished) Belgian draft system amounted to twice its budgetary cost.

A military draft shares with all other taxes the feature that it is not neutral but rather induces substantial avoidance activities and, thus causes economic distortions and deadweight losses. For example, conscription goes along with various ways of “dodging”, inefficient employment, preemptive emigration, pretend schooling, hasty marriages and other reactions. Russia's statutory two-year draft is avoided by more than $90 \%$ of the eligible men, using means such as fake medical certificates, university studies, bribery, or simply avoiding going to drafting stations (Lokshin and Yemtsov, 2008). Maurin and Xenogiani (2007) find that higher education enrollment of males in France has decreased since conscription was (de facto) abolished in 1997 for men born in 1979 or later. The study points to the fact that some men may have attended higher education to postpone their military duties, possibly hoping to completely circumvent service at a later date. A similar effect is shown by Card and Lemieux (2001) for males who were at the risk to be drafted to the U.S. Army during the Vietnam War.

An all-volunteer force also inflicts distortionary effects on the economy through the taxes needed to finance the system. From an economic perspective the

$6 \quad$ According to Oneal (1992), budgetary savings from conscription in NATO states reduced from an average of $9.2 \%$ of national military expenditures in 1974 to only $5.7 \%$ in 1987 . Warner and Asch (2001) report that the budgetary costs of moving to a volunteer force in the USA in 1973 came at 10 to $15 \%$ of the 1965 military budget (which was chosen as a reference point to exclude the effect of the Vietnam War). 
question of "military draft versus professional army" is a problem of optimal taxation: select that type of taxation that minimizes distortions. In general, conscription appears to be inferior and, thus, should be avoided. However, Lee and McKenzie (1992), Warner and Asch (1995), and Gordon et al. (1999) argue that a military draft could, under certain circumstances and beyond some recruitment level, be the less costly tax instrument- - e.g., if the level of fiscal taxation (to finance non-military expenditure) is already very high. Warner and Negrusa (2005) suggest that differences in deadweight losses (e.g., through evasion) for fiscal taxes could rationalize why some countries rely on conscripts and others do not.

Clearly, the amount of resources that have to be provided for the military may affect the optimal tax mix (Friedman, 1976). Also countries without conscription during peacetime retain the option to re-introduce conscription in case of war - when it might be infeasible to mobilize the necessary resources through fiscal taxes alone. Similar arguments may explain the use of conscription in countries such as Israel, where the military doctrine relies on the ability to mobilize most citizens to military service in case of a large-scale conflict. Mjoset and van Holde (2002) recount plenty of historical anecdotes that suggest a positive correlation between the military threat perceived by countries and their use of conscription. The recent abolishment of military draft in several European countries can then be explained - from an optimal tax perspective - by (the perception of) decreasing threats to national security in the wake of the collapse of the communist block.

\subsection{Dynamic effects}

In wartime, conscripts are forced to risk life and limb, and being drafted in peacetime at least means losing discretion over one's use of time. The specific timing of military service at an early age of economic adulthood entails dynamic extra costs which have to be added to the static opportunity costs. Draftees, when forced to work in the army at a young age, have to postpone or interrupt college or university education, fall behind in experiences on their normal jobs, or see parts of the human capital they accumulated before the draft depreciating during military service.

On the individual level, a draft system results in a substantially lower lifetime wage profile (with income losses of between 5 and 15 percent), an effect which is also 
documented empirically (Imbens and van der Klaauw, 1995; Angrist, 1990; Buonanno, 2006). ${ }^{7}$ These effects are not confined to males, but seem to matter society-wide. For example, in the case of a local and temporary abolition of military conscription in Italy, Cipollone and Rosolia (2007) show it increased educational attainment of both males and females. They explain this contagion by peer-group effects and social interaction: when teenage boys stayed longer at high school, also girls increased their participation.

On the macroeconomic level, the disruption of human capital investments by military conscription translates into lower stocks of human capital, reduced labor productivity, and substantial losses in GDP (Lau et al., 2004). From 1960 to 2000, GDP growth rates in OECD countries with conscription were lower by around a quarter percent than in OECD countries with professional armies (Keller et al., 2009), which is remarkably large given that military expenditure or the size of the military labor force per se do not seem to exert any systematic effect on GDP and its growth (Dunne et al., 2005).

\section{$2.4 \quad$ Intergenerational issues}

Economically, but also from a political perspective, a military draft shares many features of government debt or of pay-as-you-go pension schemes. In both cases its introduction is a (temporary) way around higher fiscal taxes, the static inefficiencies will remain largely unnoticed, and its dynamic costs will only start to become visible after a time lag that by far exceeds the usual presidential or parliamentary terms. The draft involves intergenerational redistribution to the extent that it one-sidedly levies parts of the costs for the provision of government services on young cohorts. Like an unfunded pension scheme, starting a draft scheme amounts to giving a "present" (in the form of a reduced fiscal tax burden) to the cohorts that are beyond draft age at that moment. Such a gift may be handed over from cohort to cohort, but it can never be accomplished such as to make everybody in the future equally well off as without the gift (Poutvaara and Wagener, 2007b).

With generally low educational attainment of the young male workforce, spending some time in the military may increase the quality of human capital by providing training opportunities for self-discipline, communicative skills, or problem-solving techniques. This seems to be empirically relevant for African and Latin American countries (Stroup and Heckelman, 2001). 


\section{The public choice perspective on military conscription}

\subsection{Theory}

The military draft is a highly discriminatory tax with respect to age, gender, and social status. $^{8}$ From the perspective of political economy, the specific (statutory or economic) incidence is precisely what might make military conscription politically attractive.

The public choice approach to political economy posits that, regardless of the (likely) inefficiency or injustice of the military draft, democratic regimes will choose to establish or maintain conscription if the majority of voters find it less costly or more socially beneficial than a professional army. As argued before, those directly burdened by the draft (namely, males at and below draft age) are largely outnumbered by those who are not directly affected by the draft (i.e., all males above draft age and all females). By contrast, the fiscal bill for the higher tax burden involved with a professional army would visibly hit everybody. In a simple majority vote among selfish taxpayers, a military draft is a winning alternative over a professional army (already see Oi, 1967). This holds even when taxpayers anticipate that the budgetary cheapness of military conscription is a fiscal illusion (Posner, 2003, pp. 490f.). For reasons of minimizing political resistance non-democratic regimes may also find military conscription attractive (apart from allowing for political indoctrination or the build-up of numerically large armies) as only a small fraction of the population with political relevance is at or below the draft age.

The similarity of military conscription with a pay-as-you-go pension scheme and its intergenerational incidence also helps to explain why draft systems continue to be maintained though they impose a higher future burden on the economy than an allvolunteer force. Given its dynamic inefficiency, a draft system, once introduced, could be replaced by an all-volunteer force in a Pareto-improving manner (i.e., with

$8 \quad$ Also see Section 4.1. In addition, the draft tax generally involves an unequal treatment even within its original target group. As cohort sizes outnumber requirements for military personnel, typically only a fraction of those who are legally subject to the draft are indeed called to service. 
unanimous political support) - but only if age-specific fiscal taxes are available. ${ }^{9}$ Given that such taxes are infeasible and given that age cohorts beyond the draft age largely outnumber younger cohorts at or below the draft age, both the continuation and the introduction of the military draft garner widespread political support in democratic as well as in non-democratic regimes. The casual observation that the staunchest advocates of conscription usually come from an age group very well above draft age supports this view.

The draft's specific incidence makes it especially appealing in ageing societies where older cohorts gain in political weight. Ironically, however, it is ageing societies for which military draft is a particularly bad idea (in spite of its potential to deliver a large number of conscientious objectors who are cheaply employable in old-age homes, care units, and similar welfare institutions). Not only are the distortions in the allocation of human and physical capital more damaging when young people become relatively scarcer; in ageing societies that already load the lion's share of the burden of demographic transitions on younger generations via pay-as-you-go financing of pensions and health care, draft systems unduly acerbate intergenerational imbalances.

\subsection{Empirical evidence}

There are only a limited number of studies on public support for the military draft. Attitudes appear to differ widely across countries and over time. Surveying polls among young citizens from EU countries in the late 1990s (especially from a Eurobarometer study in 1997), Manigart (2003) finds that support for a reintroduction of military conscription in countries that had recently abolished it was very low. For countries that were (then) running a draft scheme, approval rates varied considerably, ranging from 79\% in Greece to 13\% in Spain. Cronberg (2006) reports conscription in Finland enjoys the full support of $79 \%$ of the Finnish population, while the number for Sweden was 36\%. Subsequently, Sweden decided to abolish conscription during peacetime, while Finland maintains it. For Russia, opinion polls in 2002 and 2003 found that $60 \%$ of the population would have supported transition to

$9 \quad$ See Poutvaara and Wagener (2007b). Tax exemptions for cohorts beyond draft age are needed to avoid a double burden on those who have already delivered their military service and who would, upon abolition of draft, suffer from the higher fiscal taxes that go to finance the allvolunteer force. 
a professional army (Gerber and Mendelsohn, 2003); still the country is running a draft scheme (supported by 30\%). In Germany the picture is less clear-cut, with changing majorities for and against military conscription every now and then. ${ }^{10}$ Flynn (1998, 2001) documents that military conscription in France (1996), Britain (1960), and the United States (1973) was abolished although the draft had public support from a majority of voters in principle; what made the draft so highly unpopular in the U.S. was its biased selectiveness in the Vietnam War. ${ }^{11}$

Based on expert questionnaires in 22 European countries from 2001 and 2005, Haltiner and Szvircsev Tresch (2008) find that the incidence of the draft tax and the implied inequality in burden-sharing (a constantly diminishing number of young men are drafted) are a major cause for the waning support for military conscription in Europe. The other causes are a lack of military threat after the end of the Cold War and the increased frequency of overseas operations. Taken together, these findings suggest only a limited support for the hypothesis that the military draft is supported as a way for taxing a minority. It appears that those European countries in which the draft receives widest popular support, like Finland, Greece, and Switzerland, are all relatively small and adhere to a military doctrine that requires being able to defend against a large-scale invasion by land. By contrast, popular support for conscription in larger countries with a military draft (say, Russia or Germany) seems to be lower. From the political economy perspective of taxing a minority this is puzzling, since the size of the country should not matter for that argument.

Age-related issues of military conscription may matter for political economy. Flynn (2001, p. 226) reports for France in the 1990s that two thirds of all Frenchmen who had already delivered military service were in favor of conscription, but only $40 \%$ of those who had not yet done so had a favorable view. This age pattern is in line with the predictions from public choice theory.

\footnotetext{
10 According to Infratest (2003), 54\% of the Germans supported abolition of conscription in December 2003; a month later (and without apparent reason) that rate dropped to $41 \%$.

The U.S. draft during the Vietnam War had escape clauses that favored young men from the upper and middle classes and from wealthy backgrounds. In particular, deferments were available to all full-time college and graduate students (but not for part-time students). For college graduates, further deferments were available if one worked in a defense-related industry, or in exempted professions, like teaching.
} 


\section{Social and political record of military conscription}

The public choice perspective presented above implicitly assumed that political agents are self-concerned and care for their own welfare only ("pocketbook voting”). Yet there is ample evidence of other-concerning preferences which then might give rise to unselfish (sociotropic) political attitudes, thereby voters care about society at large, rather than their narrow self-interest. The military draft, in particular, is often debated in non-individualistic terms. Social, moral, political and military aspects may add to (or subtract from) the political allure of the military draft and, thus, contribute to an explanation as to why countries opt for that recruitment scheme. In this section, we ask whether equity considerations, social cohesion and national identity, or democratic control of the army, could explain the use of military conscription.

\subsection{Equity issues}

Advocates of the military draft argue that a conscript military is more "representative" of society than a professional army that (allegedly) preys disproportionately on the poorly educated, the lower classes, ethnic minorities or otherwise marginal(ized) strata of society. Conscription appears more egalitarian since all are included in universal service. It is seen to instill a sense of the moral duties of citizenship from which nobody is exempted (see Sandel, 1998, or Galson, 2004).

In fact, there is hardly any reason to believe that conscription makes the military (more) representative. ${ }^{12}$ First, to have a genuine cross-section of the population in the army was never the aim in conscription countries: Even at its peak, conscription covered substantially less than 50 percent of the population; it excluded women, migrants, and often certain religious groups, fathers, or gays (Leander, 2004). Second, even within its target group (young males), the military draft is biased. For the U.S., today blamed for staffing their professional army mainly with underprivileged minorities and lower-class

12 This point was forcefully made by the Gates Commission, whose report led to the abolition of the draft in the U.S. in 1970 (Gates et al., 1970, pp. 63f). But even if military conscription were egalitarian, that would not be a convincing argument in its favor. The existence of a civic duty (e.g., to defend one's country) does not imply that the burden from that duty be shared equally. Arguably, contributing to the financing of government is also a civic duty - but the idea that everybody pays the same amount of taxes is neither a logical nor probably a socially desirable implication of that duty. 
whites, analysis of Vietnam era veterans indicates that individuals of high socioeconomic status were widely underrepresented among draftees (Angrist, 1990). In Germany, males with higher educational status are more likely to be called to service than their peers with lower status (Schneider, 2003). In the Philippines, military training is compulsory for male college and university students while conscription for other groups in the population does not exist (WRI 2009). By contrast, 24 out of the 95 countries with a military draft covered in Mulligan and Shleifer (2005) have shorter terms for college students, eleven of them with complete exemption. Legal and illegal buyout options favor wealthy, urban, and well-educated citizens.

\subsection{Social cohesion and national identity}

Conscription is sometimes viewed as a "melting pot" for diverse ethnic or social groups that would otherwise have little mutual contact, thereby forging national identity, loyalty to the nation, or social respect. ${ }^{13}$ Military service is often hailed as the "school for the nation”, and civic, political and historical education often is a formal requirement for conscripts.

Empirical evidence for the military's power as a socializing agent is, at best, mixed (for an extensive survey see Krebs, 2004). Moreover, it may be questioned whether forced labor in a military environment is an appropriate means to promote social cohesion, even when combined with deliberate civic instruction. Primary and secondary schooling, integration of minorities, policies targeted at underprivileged groups in society etc. appear to be far more promising, in particular as they approach the root of the problem.

\subsection{Armed forces and democracy}

Military conscription is often attributed with a greater affinity with democracy than an all-volunteer force. Army structures, which operate on the basis of order and conscription in Malaysia, Singapore, South Africa, and Israel. 
command rather than on voting, are inherently non-democratic. Still conscripts may act as mediators between a society and its army, while a professional military tends to alienate from society and form a "state within a state".

However, the "isolation" of the military from the rest society may be indicative of an increased division of labor. In a certain sense, employees in bakeries, courts of justice, and universities are also alienated in their work from the rest of society, but calls for compulsory internships of all members of society in such sectors have so far been unheard of. Even if one views the alienation of the military from the rest of society as particularly undesirable, conscription does not offer a solution. Praetorian tendencies are most likely to emerge from the officers' corps (the "warrior caste”) which in any case consists of professional soldiers. Moreover, the democratic controls arising from a draft are open to debate. Not only were conscript forces used by totalitarian regimes (Nazi-Germany, the Soviet Union, or Fascist Italy) without noticeable resistance from within the army, but also democratic countries like Argentina (in 1976), Brazil (in 1963), Chile (in 1973), Greece (in 1967), and Turkey (in 1980) used conscription at the time of their military coups. Combined with the fact that many democracies have adopted the all-volunteer system without ever facing the risk of military coups, these observations as well as the econometric evidence established by Mulligan and Shleifer (2005) indicate that no causality in whatever direction exists between the form of government and the structure of armed forces in a country.

\section{Conscription and special interests}

The military draft does not burden all segments of society or sectors of the economy equally. Such differential incidence gives rise to special interests - which might shape the political process.

For Anglo-Saxon countries, Levi (1996) finds that decisions in favor or against military conscription are not so much driven by strategic, military or fiscal factors but rather by the ability of the opponents of conscription to transform their views into political clout. The cleavages against the draft fell into three main categories: ideological groups (left-wing political parties, anarchists, and pacifists); economic groups (some labor unions and farmers' lobbies) that feared to be the 
primary losers from universal conscription; and religious, ethnic, and other cultural groups (the Irish in Britain or the Francophones in Canada) that had lost confidence in government promises.

Anderson et al. (1996) suggest that members of labor unions will favor conscription as it keeps potential competitors off the private labor market, thus allowing for a higher wage for unionized workers. In fact, empirical evidence in Anderson et al. (1996) reveals a positive correlation between the percentage of the workforce in labor unions and the use of conscription.

When available, the option to do alternative rather than military service is exercised by a considerable share of draftees. For their employers, conscientious objectors to military service -- who mainly deliver their duties in the social sector -are quite attractive staff as they are cheap, have to work on order, and their employment is not subject to the restrictions imposed by labor laws. This adds issues of rent-seeking to the debate on military conscription. The disappearance of alternative service (which, by legal design, is only a corollary to compulsory military service), is used as an argument against the abolition of military conscription. Afraid of losing economic rents, the welfare industry actively lobbies for conscription (or even for a universal national service to be delivered by youths of both genders), arguing that many nursing and care services could not be upheld in their present form without conscription, with the cost falling mainly on the most needy and disadvantaged people in society. Interestingly, such argumentation suggests that it is easier to finance the care for the elderly by imposing the costs disproportionately on the young, rather than sharing the fiscal burden over the whole population.

The military itself might also have vested interests in the conscription debate. Because conscription affects quite a large stratum in society, it gives the military a high visibility. The military might view conscription as a means to convey the importance of national defense and security to the minds of young draftees or to use its greater visibility to lobby for more resources. Conscription might also be used as an advertising mechanism for would-be professional soldiers. However, in certain circumstances the military might also be against conscription. The high administrative burden, permanent low-level training of conscripts, and the dubious military value of draftees may be seen as a distraction from the military's proper tasks. Further, the equipment of the army including weapons, materials and personnel suitable for draftees may come at the expense of more prestigious or sophisticated items. 
Frequently publicized reports by draftees about the tedium of their service (not to speak of abuses of draftees by officers) may also backfire on the perceived attractiveness of the army as a potential employer. Unfortunately, a systematic account or comparative study of the attitude towards conscription in the military itself does not currently exist.

From an organizational perspective, professional armies differ from conscript forces in that the latter need a larger administrative apparatus to operate (e.g., to register the population, enforce the draft, etc.). Hence, bureaucracies may play a role. Mulligan and Shleifer (2005) argue that countries with a lot of other government regulation are also more likely to use draft. They trace this correspondence back to the legal system under which a country is operating-either common law systems (originating from England) or civil law systems (originating mainly from Napoleonic France). Common law countries rely to a greater extent on contracts and decentralized conflict resolution, while civil law countries rely on regulation, state involvement, and public administration. Given this logic, when choosing between military conscription and professional armies, countries with larger public administrations (i.e., the civil law countries) find it more attractive to set up a conscription scheme as compared to common law countries which prefer a military draft.

\section{The military record of the draft}

In the early $19^{\text {th }}$ century, military conscription gained popularity among political leaders because of the military successes of Prussia's and France's conscript armies. However, this initial battlefield dominance later came at the huge cost of millions of deaths which at least partly can be attributed to the "cheap-labor fallacy" with conscription. Observing the carnage of Napoleon's poorly prepared winter campaigns in Russia, $19^{\text {th }}$-century German economist J.H. von Thuenen argued that this negative outcome could only happen after soldiers became easily available through the system of conscription. Von Thuenen (1875, pp. 154f) reasoned that the scandalous misperception in military recruitment of those times was to view human life as a commodity and not as a capital good (see also Kiker, 1969; Spencer and Woroniak, 1969; Knapp, 1973). 
Compulsory service and the perception of draftees as cheap labor are likely to lead to an inefficient organization within the military. In peacetime, this excessive labor-to-capital ratio manifests itself in an often-lamented tedium of service, the overmanning of army units, and the excessive maintenance devoted to weapons and materials (Straubhaar, 1996). In wartime, the use of less advanced military technology, lack of experience and training, poor equipment and the easy availability of apparently expendable soldiers leads to a larger number of casualties and "cannonfodder”-type battlefield tactics (e.g., trench wars, human-wave attacks etc.).

Despite the use of conscription in most wars in the $19^{\text {th }}$ and $20^{\text {th }}$ centuries, advocates of conscription sometimes contend that using a military draft breaks militaristic ideologies of societies and limits the inducement for aggressive foreign interventions. By imposing casualties on all groups of society, military adventurism is politically less sustainable and faces greater public resistance with a draft system. Hence, a peace-loving population would opt for military conscription rather than for professional soldiers. Empirically, this “peacemaker” argumentation is questionable. As argued by many opponents of conscription, the draft may actually contribute to a militarization of society. By teaching all (male) citizens how to use weapons and kill, and instilling in them the view that killing for the home country is a patriotic duty, draft fosters processes by which civil societies organize themselves for the production of violence, and thereby increases the likelihood and severity of armed conflicts. ${ }^{14}$ Between 1800 and 1945, basically all wars in Europe were fought with conscript armies, and democratic countries like the U.S. and France later used conscript military in their colonial wars in Vietnam and Algeria. Analyzing militarized interstate disputes from 1886 to 1992 systematically, Choi and James (2003) find that a military manpower system based on conscripted soldiers is associated with more military disputes than professional or voluntary armies. Based on cross-sectional data from 1980 Anderson et al. (1996) conclude also that "warlike” states are more likely to rely on conscription.

Interacting conscription with democracy seems to change the picture somewhat. Vasquez (2005) empirically demonstrates that, for the second half of the $20^{\text {th }}$ century, military drafts, as compared with volunteer forces, tend to have a

14 This point is most voicefully made in the famous Anti-Conscription Manifesto (see http://www.themanifesto.info/manifesto.htm). For a thorough historical account for Germany, see Frevert (2004). 
mediating effect on the number of casualties that democratic countries are likely to suffer in military disputes. He argues that democracies with conscription pursue casualty-averse policies out of concern for political backlash that could come from the most powerful segments of society that contribute troops to the force.

Another consideration is that compulsory military service provides manpower reserves to augment the army in the case of military emergency. This might provide a precautionary motive for using the draft. The validity of this argument depends on whether reservists are indeed suitably trained for their assignments in the case of mobilization, which may be doubtful, given the concerns about the inadequacy of conscripts' training for the requirements in modern armies even during peacetime. Moreover, establishing an all-volunteer army in no way implies giving up reserves, provided that reservists are paid sufficient compensation for their participation in regular exercises. Contracted (as contrasted to conscripted) reservists would render the full opportunity costs of alternative military strategies visible and help to allocate resources more efficiently between personnel and material.

\section{Mercenaries}

Historically, military conscription emerged from an era of commercialized warfare that heavily relied on mercenaries. Given the questionable record of forced labor in the military on several accounts, "market solutions" appear more attractive. This is not only evidenced by the recent shifts in many countries from the military draft to professional armies, but is also reflected in the fact that private military companies, which operate on a world-wide scale, have recently been booming (Singer, 2004). ${ }^{15}$ This trend has raised serious concerns among many observers, but the question of what precisely makes mercenaries morally or politically questionable is complicated (Sandel, 1998; Percy, 2007).

From the viewpoint of political economy, hiring (foreign) mercenaries in armed conflicts might reduce the political costs of casualties and also of committing atrocities; after all, it is only a contracted hireling who loses his health or life or who

15 As Saudi-Arabia evidences, even standing armies can be staffed with hired foreigners. Also, the Vatican City's picturesque Swiss Guard is a professional army exclusively hired from abroad. 
"misbehaved”. Reluctance to employ mercenaries on a large scale may stem from severe principal-agent problems. Already Machiavelli (1532, Ch. 12) favored conscription as the way to raise an army, arguing that, by virtue of their citizenship, even comparatively untrained militia conscripts were better defenders than professional hirelings from abroad. While defection of mercenaries merely amounts to non-compliance with the terms of a labor contract, desertion of citizens from their country’s army is typically heavily penalized, stigmatized, and often goes along with abandoning one's home country. The higher exit costs and, arguably, the higher idealistic motivation provides two arguments for why national soldiers are a better option than mercenaries. ${ }^{16}$

Armies staffed by non-citizens are not doomed to be unreliable. While an Italian state in Machiavelli's time would typically contract an entrepreneurial commander with a mercenary army of unspecified origins, the French government directly hires individual soldiers into its Légion étrangère. Admission to the legion is (nowadays) severely restricted, and recruits, who come from diverse backgrounds and nationalities, undergo a unifying training to generate a strong esprit de corps. The legion's composition and structure follow that of a regular army, and commanding positions are trusted only to long-serving soldiers with a reliable record, mainly to French citizens. After three years of service (or after being injured in a battle for France), foreign legionnaires can apply for French citizenship. These structures and incentives help to avoid that mercenaries would organize themselves against the state that hired them.

\section{Conclusion}

We have documented that the normative case for conscription is weak, both from efficiency and from non-economic perspectives. The inefficiency of conscription results to a great extent from ignoring comparative advantage and specialization,

$16 \quad$ For a government, hiring mercenaries means outsourcing parts of its monopoly over (armed) violence. In low-intensity conflicts and temporarily, this might be hardly noticeable. Van Creveld (1991) argues, however, that over time selling away the monopoly of power inevitably threatens sovereignty and the existence of the state as such. 
thereby resulting in higher social costs than a voluntary army. At the same time, there is no empirical support for the claim that the use of conscription would help to protect democracy, promote social cohesion or tame belligerence. Political economy explanations for the use of conscription in democratic regimes have a somewhat mixed record. While some evidence suggests that conscription is welcomed as a way to shift a tax burden to a minority, the changes in public opinion suggest that this is only part of voter considerations. Conscription tends to be more popular the more universal it is among young men. Fairness concerns requiring equal treatment of youngsters seem to stop at the gender line as voters by and large seem to accept conscription affecting only men. In democratic systems, the military draft continues to be maintained not least due to some inertia in the political process. The draft cannot be abolished in an intergenerationally Pareto-improving manner and special interest groups voice their "concerns" against its abolition loudly which contributes to the maintenance of the status quo.

In non-democratic regimes - which are currently the dominant users of conscription - popular support for conscription is less politically relevant. In these cases, aspects of indoctrination (or even intimidation), as well as the desire to maintain numerically large armies, seem be important factors for relying on the draft. For developing countries, with their inability to raise enough fiscal revenues to finance an all-volunteer force and with their generally lower opportunity costs of labor, the military draft could even be economically attractive.

In democratic countries with developed economies, military conscription has run its course. Historically, it might have been a useful and even popular military recruitment device when these countries were involved in mass warfare or nation building or only had limited capacities to raise fiscal taxes. With the possible exception of states that view themselves under permanent military threat that requires all citizens to be militarily trained, the present-day political, economic and military conditions are unfavorable for the survival of the draft. 


\section{References}

Anderson, G. M., D. Halcoussis and R. D. Tollison (1996), 'Drafting the Competition. Labor Unions and Military Conscription', Defence and Peace Economics 7, 189-202.

Angrist, J. D. (1990), 'Lifetime Earnings and the Vietnam Era Draft Lottery: Evidence from Social Security Administration Records', American Economic Review 80, 313-335.

Avant, D. (2000), 'From Mercenary to Citizen Armies: Explaining Change in the Practice of War', International Organization 54, 41-72.

Buonanno, P. (2006), 'Costs of Conscription: Lessons from the UK'. University of Bergamo, Department of Economics Working Paper No. 04/2006.

Card, D. and Th. Lemieux (2001), 'Going to College to Avoid the Draft: The Unintended Legacy of the Vietnam War', American Economic Review 91, 97-102.

Choi, S.-W. and P. James (2003), 'No Professional Soldiers, No Militarized Interstate Disputes? A New Question for Neo-Kantianism', Journal of Conflict Resolution 47, 796-816.

Cipollone, P. and A. Rosolia (2007), 'Social Interactions in High School: Lessons from an Earthquake’, American Economic Review 97, 948-965.

Cronberg, Tarja (2006), 'The Will to Defend: A Nordic Divide over Security and Defence Policy', in Alyson J. K. Bailes et al. (eds), The Nordic Countries and the European Security and Defence Policy, Oxford: Oxford University Press, pp. 315322.

Dionne, E.J., Kayla Meltzer Drogosz and Robert E. Litan (eds) (2003), United We Serve. National Service and the Future of Citizenship, Washington D.C.: Brookings Institution Press. 
Dunne, J. P., R. P. Smith and D. Willenbockel (2005), 'Models of Military Expenditure and Growth: A Critical Review’, Defence and Peace Economics 16, 449461.

Galston, W. A. (2004), 'Thinking About the Draft', Public Interest 154 (winter 2004), 61-73.

Flynn, George Q. (2001), Conscription and Democracy: The Draft in France, Great Britain, and the United States. Westport: Greenwood Press.

Flynn, G. Q. (1998), 'Conscription and Equity in Western Democracies, 1940-75’, Journal of Contemporary History 33, 5-20.

Frevert, Ute (2004), A Nation in Barracks: Modern Germany, Military Conscription and Civil Society, Oxford: Berg.

Friedman, M. (1967), 'Why Not a Volunteer Army?', New Individualist Review. Spring 1967, 3-9.

Gates, Thomas et al. (1970), The President's Commission on an All-Volunteer Armed Force. Washington D.C.

Gerber, Th. P. and S. E. Mendelson (2003), 'Strong Public Support for Military Reform in Russia'. PONARS Policy Memo 288, Centre for Strategic and International Studies, Washington D.C.

Globaldefence.net (2009), http://www.globaldefence.net/, accessed on 20 August 2009.

Gordon, R. H., C.-E. Bai and D. D. Li (1999), 'Efficiency Losses from Tax Distortions vs. Government Control’, European Economic Review 43, 1095-1113. 
Haltiner, Karl W. (2003), 'The Decline of the European Mass Armies', in Giuseppe Caforio (ed.), Handbook of the Sociology of the Military, New York: Kluwer/Plenum Publishers, pp. 361-384.

Haltiner, K. W. (1998), 'The Definite End of the Mass Army in Western Europe?', Armed Forces \& Society 25, 7-36.

Haltiner, Karl W. and Tibor Szvircsev Tresch (2008), 'European Civil-Military Relations in Transition: The Decline of Conscription', in Giuseppe Caforio et al. (eds), Armed Forces and Conflict Resolution: Sociological Perspectives, Bingsley: Emerald Publishing Group, pp. 165-182.

Imbens, G. and W. van der Klaauw (1995), 'Evaluating the Cost of Conscription in The Netherlands', Journal of Business and Economic Statistics 13, 207-215.

Infratest (2003), Deutschland TREND (Dezember 2003), http://www.infratestdimap.de/uploads/media/dt0312.pdf, accessed 20 August 2009.

Keegan, John (1993), A History of Warfare, New York: Alfred Knopf.

Keller, K., Poutvaara, P. and A. Wagener (2009), 'Military Draft and Economic Growth in OECD Countries’, Forthcoming, Defence and Peace Economics.

Kerstens, K. and E. Meyermans (1993), 'The Draft versus an All-Volunteer Force: Issues of Efficiency and Equity in the Belgian Draft', Defence Economics 4, 271-284.

Kiker, B.F. (1969), 'Von Thünen on Human Capital', Oxford Economic Papers 21, 339-343.

Knapp, C.B. (1973), 'A Human Capital Approach to the Burden of the Military Draft', Journal of Human Resources 8, 485-496.

Krebs, R. (2004), 'A School for the Nation? How Military Service Does Not Build Nations, and How it Might', International Security 28, 85-124. 
Lau, M. I., P. Poutvaara and A. Wagener (2004), 'Dynamic Costs of the Draft', German Economic Review 5, 381-406.

Leander, A. (2004), 'Drafting Community: Understanding the Fate of Conscription', Armed Forces \& Society 30, 571-599

Lee, D. R. and R. B. McKenzie (1992), 'Reexamination of the Relative Efficiency of the Draft and the All-Volunteer Army', Southern Economic Journal 59, 646-654.

Levi, Margaret (1998), 'Conscription: The Price of Citizenship’, in Robert H. Bates et al. (eds), Analytic Narratives, Princeton: Princeton University Press, pp. 109-148.

Levi, M. (1996), ‘The Institution of Conscription’, Social Science History 20, 133167.

Lokshin, M. and R. Yemtsov (2008), 'Who Bears the Costs of Russia's Military Draft?', Economics of Transition 16, 359-387.

Machiavelli, Niccolo (1532 [written in 1515]), Il Principe, translated and reprinted in George Bull (ed) (2001), The Prince, Harmondsworth: Penguin.

Manigart, Philippe (2003), 'Public Opinion on Defence Policy in the Countries of European Union', in Maria Vlachová (ed), The Public Image of Defence and the Military in Central and Eastern Europe, DCAF and Centre for Civil-Military Relations: Geneva/Belgrade, pp. 27-46.

Maurin, E. and Th. Xenogiani (2007), 'Demand for Education and Labor Market Outcomes: Lessons from the Abolition of Compulsory Conscription in France', Journal of Human Resources 42, 795-819.

McNeill, William H. (1982), The Pursuit of Power: Technology, Armed Force, and Society since A.D. 1000, Chicago: The University of Chicago Press. 
Mjoset, Lars and Stephen van Holde (2002), 'Killing for the State, Dying for the Nation: An Introductory Essay on the Life Cycle of Conscription into Europe's Armed Forces', in Lars Mjoset and Stephen van Holde (eds), The Comparative Study of Conscription in the Armed Forces, Amsterdam: JAI Press, pp. 4-98.

Mulligan, C. and A. Shleifer (2005), 'Conscription as Regulation', American Law and Economics Review 7, 85-111.

Peled, Alon (1998), A Question of Loyalty: Military Manpower Policy in Multiethnic States, Cornell University Press: Ithaca.

Percy, Sarah (2007), Mercenaries. The History of a Norm in International Relations, Oxford/New York: Oxford University Press.

Posner, Richard A. (2003), Economic Analysis of Law (6th edition), New York: Aspen Publishers.

Poutvaara, P. and A. Wagener (2007a), 'Conscription: Economic Costs and Political Allure', Economics of Peace and Security Journal 2, 5-15.

Poutvaara, P. and A. Wagener (2007b), 'To Draft or Not to Draft: Inefficiency, Intergenerational Incidence, and Political Economy of Military Conscription', European Journal of Political Economy 23, 975-987.

Sandel, M. J. (1998), ‘What Money Can’t Buy: The Moral Limits of Markets’, Tanner Lectures on Human Values, University of Utah.

www.tannerlectures.utah.edu/lectures/documents/sandel00.pdf, accessed on 20 August 2009.

Sandler, Todd and Keith Hartley (1995), The Economics of Defense, Cambridge: Cambridge University Press. 
Schneider, T., (2003), 'Wehr- und Zivildienst in Deutschland: Wer dient, wer nicht? [Military and Alternative Service in Germany: Who Serves and Who Doesn't?]', Jahrbücher für Nationalökonomie und Statistik 223, 603-622.

Singer, Peter W. (2004), Corporate Warriors: The Rise of the Privatized Military Industry, Ithaca: Cornell University Press.

Smith, Adam (1776), An Inquiry into the Nature and Causes of the Wealth of Nations, reprinted in W. B. Todd (ed) (1976), Glasgow Edition of the Works and Correspondence of Adam Smith, Vol. I, Oxford: Oxford University Press.

Spencer, D. L. and A. Woroniak (1969), 'Valuing Transfer of Military-Acquired Skills to Civilian Employment', Kyklos 22, 467-492.

Straubhaar, Thomas (1996), 'Einsparpotenziale bei den Verteidigungsausgaben: Die allgemeine Wehrpflicht' [Potential Economies in Defense Expenditures: Military Conscription] , in Dieter Fritz-Assmus and Thomas Straubhaar (eds.), Sicherheit in einem neuen Europa, Berne: Haupt, pp. 267-299.

Stroup, M. D. and J. C. Heckelman (2001), 'Size of the Military Sector and Economic Growth: A Panel Data Analysis of Africa and Latin America', Journal of Applied Economics 4, 329-360.

Thuenen, Johann Heinrich von (1875), Der isolierte Staat in Beziehung auf Landwirtschaft und Nationalökonomie (3rd edition), Berlin: Wiegardt, Hempel \& Parey. (English edition: Isolated State (1966), Pergamon Press: Oxford/New York).

Van Creveld, Martin (1991), The Transformation of War, New York: The Free Press.

Vasquez, J. P. (2005), 'Shouldering the Soldiering: Democracy, Conscription, and Military Casualties', Journal of Conflict Resolution 49, 849-873.

Warner, J. T. and B. J. Asch (2000), 'The Record and Prospects of the All-Volunteer Military in the United States', Journal of Economic Perspectives 15, 169-192. 
Warner, J. and Negrusa, S. (2005), 'Evasion Costs and the Theory of Conscription', Defense and Peace Economics 16, 83-100.

Wikipedia (2009), Keyword "Conscription”, http://en.wikipedia.org/wiki/Conscription, accessed on 20 August 2009.

WRI (2009), World Survey of Conscription and Conscientious Objection to Military Service, War Resister's International: London, http://www.wriirg.org/co/rtba/index.html, accessed on 20 August 2009. 